\title{
INTRODUCTION TO UKRAINIAN COMMERCIAL LAW
}

\section{Lazur Ya. V.}

\section{INTRODUCTION}

Since Ukraine gained its independence, there have been changes in economic management approaches and principles according to which "state-business relations" are established, effective state regulation of entrepreneurship in the form of the single state regulatory policy in the field of entrepreneurship has been introduced, etc.

Ukraine's integration into the world economy promotes the development of international business relations and entrepreneurs' international economic activity.

There have emerged new institutions that are typically involved in market conditions of running businesses: bankruptcy, freedom of competition, antitrust regulation, etc. Privatization processes are being stimulated and equity market is being significantly developed.

Hence, in order to ensure sustainable economic growth of Ukraine and its integration into the world community it is necessary to provide the proper legal and regulatory environment for business processes. All these factors stipulate the necessity for the proper regulatory framework as well as studying fundamental legal principles of business activities, which are the subject-matter of commercial law.

However, home legal science is known to be preoccupied with an issue that appears especially relevant today in spite of having been discussed by scholars for many decades. This entails the issue of identifying commercial law as a special field of law.

Taking into account a significant body of research into the issue in question it may be claimed that this issue has been given careful consideration. However, there is a marked divergence in scholars' opinions on the legal nature of commercial law.

Hence, this article is aimed at justifying the integrity and cohesiveness of commercial law as a field of law and providing reasons for the topicality and expediency of its existence by means of examining its main institutions.

\section{The concept, subject and methods of commercial law}

The becoming and development of commercial law as a brunch of law is inextricably linked by the technical and social revolution of the beginning of the last century. In some countries the formation of the commercial law as independent branch of law occurred on the basis of the trade and industrial 
laws. In the other countries the commercial law became an independent branch of law based on legislation, which appeared in connection with the regulation of a new type of public relations related to the organization and implementation of economic activity.

In the legal system of Ukraine, the commercial law is a relatively young branch of law. In the formative period of Ukraine as an independent state, the subject of legal regulation narrowed to entrepreneurial activity, owing to with the new trends of national legal science. However, nonprofit business activity was not include in the sphere of legal regulation and it did not correspond to reality of the economic situation in the country.

The final understanding of the subject of legal regulation was formed only with the adoption on January 16, 2003 of the Commercial Code of Ukraine (hereinafter CC Ukraine). ${ }^{1}$ In accordance with article 1 the subject of commercial-legal regulation are commercial relations. They arise as the result of the process of organizing and implementation commercial activities between entities and also between these entities and other participants of economic relations in commercial sphere.

The modern legal doctrine has a dominant approval that the subject of commercial law is defined by two concepts: functional - "organization of commercial activity" and subjective - "implementation of commercial activity".

The functional aspect of the subject of legal regulation is defined by the national legislator - the activity of subjects of the commercial relations in the social production, which is aimed to manufacturing and selling the products, to completing of the work or the provision of value-added services having price certainty.

Commercial activity can be carried out on a business or non-profit basis. In the first case, making profit as the goal of doing business, in the second about achieving a certain socio-economic result without making a profit.

The method of commercial law is a set of methods for the regulatory impact of the norms of commercial law on the behavior of subjects of commercial legal relations.

1. The method of prescriptions: provides for the right to make legally significant decisions by the governance body (property owner) in relation to a subject subordinate to it (the decision of the owner to create an enterprise or reorganize it, liquidate it, issue a license or cancel it, place a state order at enterprises which operating on the basis of state property, enterprises which are monopolist).

2. The method of autonomous decisions - allows commercial entities to make independently (but within their competence) legally significant

\footnotetext{
${ }^{1}$ Господарський кодекс України 16 січня 2003 року № 436-IV/ Вiдомості Верховної Ради Украӥни. 2003. № 18-22. Ст. 144.
} 
decisions and the obligation of all entities not to impede the adoption and implementation of these decisions.

3. The method of coordination ensure that the adoption of legally significant decisions by agreement between the parties, each of which is not at liberty to impose its conditions on the other side; the decision is made by compromise (conclusion of a commercial contract).

4. The method of recommendations provides for the publication by the competent authorities of offers (recommendations) addressed to commercial entities on a specific (preferably for the company, effective) and behavior (course of action) in the field of business (sample commercial contracts, sample founding and internal legal documents of commercial organizations, including open joint stock companies).

There is a theory about the existence of a single (complex) method of legal regulation. This is a method of equal subordination of all participants in commercial relations to the public commercial order, provides an optimal combination of private and public interests and creates partnership and upstanding relations in the field of business. (The position of its opponents is based on the fact that the state in the person of governance bodies has a special status, in particular, it defines those rules of public commercial order, which subsequently must be subordinated on an equal basis with other participants in economic life. However, the country (represented by governance bodies) not only establishes, but can also change these rules, testifies to its special position among participants in commercial relations as the organizer of economic life in the country).

\section{The principles of commercial law}

The subject of legal regulation of commercial law is relations, which arise in the process of organizing and implementing commercial activities in the field of economics. The principles of the commercial law based on the general principles of economics ${ }^{2}$ :

1. The optimal combination of relations of commercial entities of selfregulated market and state regulation of macroeconomic processes.

2. Economic variety - the government recognizes the possibility of existence a various forms of ownership (state, communal, collective, private) and various forms of management.

3. Recognition of all subjects of property rights equal before the law, prevention of unlawful deprivation of property.

4. The provision by the government the protection of the rights of all subjects of the right of ownership and management. This is one of the constitutional principles, which is closely related to the above and which is

\footnotetext{
${ }^{2}$ Щербина В.С. До питання щодо принципів господарського права. Вісник Південного регіонального ичентру Національної академії правових наук України. 2014. № 1. С. 88.
} 
an important guarantee for the realization by entities of the right of ownership and derivative rights of commercial management and operational management, aand also other rights with which they are entitled as commercial entities.

5. The right of everyone to entrepreneurial activity not prohibited by law.

The action of this principle is formulated in art. 43 of the Commercial Code of Ukraine ${ }^{3}$ as "freedom of entrepreneurial activity", at the same time, has certain limitations:

a) characteristics of the implementation of certain types of entrepreneurship are established by legislative acts;

b) a list of types of commercial activities, subject to licensing, further a list of types of activities in which entrepreneurship is prohibited, are established exclusively by law;

c) the implementation of entrepreneurial activity is prohibited by public authorities and local authorities;

d) the entrepreneurial activity of officials and officers of of public authorities and local self-government bodies is limited by law in cases provided for in the second part of art. 64 of the Constitution of Ukraine.

e) providing the government with protection of competition in entrepreneurial activity, preventing abuse of monopoly position in the market, unlawful restrictions on competition and unfair competition.

d) social orientation of the economy

This constitutional principle in the context of the legal regulation of relations in the economic sphere means the implementation by the government (in particular, by establishing the appropriate organizational and economic powers of public authorities, local authorities, other authorized bodies and organizations) in the socio-economic sphere of the social policy of consumer protection, policy wages and incomes, employment policies, social protection and social security policies.

\section{The concept, signs and types of commercial relations}

The implementation of commercial activity is impossible without the interaction of its entities, without their entry into commercial relations. The concept of commercial relations and commercial activity is very close in meaning. They indicate specific behavioral acts of various entities in the field of business. There are various relations, which are arising and operating in the economic sphere. They are related to economic activity, not all of which relate to commercial activity (for example, tax, civil, labor, etc.). Commercial relations have their own specificity ${ }^{4}$ :

${ }^{3}$ Господарський кодекс України 16 січня 2003 року № 436-IV/ Вiдомості Верховної Ради Украӥни. 2003. № 18-22. Ст. 144.

${ }^{4}$ Хозяйственное право: учебник / В. К. Мамутов, Г.Л. Знаменский, К. С. Хахулин и др. ; под ред. В. К. Мамутова. Київ: Юринком Интер, 2002. С. 11. 
- sphere of arise - commercial systems of any level (government - the economy of the country, territorial - the economy of a particular region, local - commercial entities / commercial organizations);

- settlement of these relations through legal commercial norms;

- special subjective composition (business entities are a mandatory participant in these relations);

- the object of commercial legal relations is property in the form of things and incorporeal semolina / intangible assets, necessary for the organization and direct implementation of commercial activities;

- content - subjective rights and obligations of participants relations in the business sphere;

- a combination of property and organizational elements;

- reflection in the commercial legal public relations.

In the process of carrying out commercial activities, horizontal or economic-production, vertical or organizational-economic and intraeconomic relations arise. It is further understood that these types of relationships are not separable.

Commercial-production relations are property and other relations that arise directly during the implementation of economic activities by commercial entities.

Organizational and business relations are understood as relations associated with the manifestation of public interest through the interaction of commercial entities and business entities in the process of managing economic activity.

Intraeconomic relations arise between the structural units of the commercial entity, and also between the commercial entity and its structural unit.

\section{Objects of commercial legal relations}

The objects of commercial legal relations are property in the form of things and incorporeal property/intangible assets (including objects of intellectual and industrial property rights), necessary for the organization and direct implementation of commercial activity. A special type of property of business entities is securities.

A «thing» as a legal category is defined in art. 179 of the Civil Code of Ukraine $^{5}$ : "the subject of the material world in respect of which civil rights and obligations may arise".

In order for things to become an object of commercial turnover, they must meet the signs enshrined in the first part of art. 139 of the Commercial Code:

- have a value expression;

- produced or used in the activities of business entities;

${ }^{5}$ Цивільний кодекс України від 16 січня 2003 року № 435-IV. Відомості Верховної Ради Украӥни. 2003. № 40. Ст. 356. 
- displayed on the balance sheet of these entities or accounted for in other statutory forms of recording property of these entities;

- displayed on the balance sheet of these entities or accounted for in other statutory forms of recording property of these entities.

Intangible assets mean as a complex of incorporeal objects that have property value and are protected by the subjective law. Intangible assets are a complex and multi-level structure, consisting of the main objects (intellectual property rights and the right to use property) and auxiliary (rights that ensure the effective implementation of comercial activities that are organizational in nature and cannot be alienated from the owner). ${ }^{6}$

Part two of art. 139 of the Commercial Code of Ukraine contains a classification of the property base of commercial entities depending on the economic form that the property acquires in the process of carrying out economic activities:

- fixed assets;

- current assets;

- cash;

- goods.

The concept of fixed assets is defined in Regulation (standard) of accounting 7 "Fixed assets". These are tangible assets that an enterprise contains for the purpose of using them in the production or supply of goods, the provision of services, leasing to other persons or for administrative and social cultural functions, the expected life of which is more than one year (or the operating cycle, if it is longer than one year).

Fixed assets include: buildings, structures, machinery and equipment, equipment, tools, industrial equipment and accessories, household equipment and other durable property, classified by law as fixed assets.

Working capital - this material values that usually are consumed during one production cycle and immediately transfer their value to the finished product. The Commercial Code of Ukraine relates to working capital raw materials, fuel, materials, low-value items and items that quickly wear out, other property for production and non-production purposes, referred by the legislation to working capital.

Money in the property of economic entities is cash in national and foreign currency, intended for the implementation of commodity relations of these entities with other entities, as well as financial relations in accordance with the law.

Goods can be expressed in the form of finished products, work and services performed.

\footnotetext{
${ }^{6}$ Гусь А.В. Правовий режим нематеріальних активів у складі майна державних вищих навчальних закладів: автореф. дис. ... канд. юрид. наук. спец.: 12.00.04. Київ, 2015. С. 10, 13.
} 122 
A special type of objects of economic legal relations is a document of the established form with the relevant details that certifies monetary or other property law. It determines the relationship between the issuer of the security (the issuer of the security) and the person having rights to the security, and provides for the fulfillment of obligations on such a security, as well as the possibility of transferring rights to a security and rights on a security to other persons ${ }^{7}$.

The main difference between the legal regime of certain types of property of business entities is the competence of the owner, which he exercises in relation to the objects belonging to him. The working capital and fixed assets are used on the basis of the competence of ownership and use, and goods and money - orders.

There are a special funds and reserves in the property of commercial entities - the funds of the enterprise / economic organization that do not directly participate in the production process, but are used for a special purpose (purpose) provided for by the legislation or the charter of the enterprise (constituent document of the economic organization). Special funds and reserves are divided into mandatory (that is, provided for by law as such) and optional, created at the discretion of the commercial entity or property owner ${ }^{8}$.

The basis of the legal regime of property of commercial entities is the right of ownership and other property rights. According to Art. 134 of the Commercial Code of Ukraine, the right of ownership is the basic property right in the field of managing, according to which a business entity that carries out economic activity on the basis of the right of ownership, at its discretion, alone, or together with other entities, owns, uses and disposes of property belonging to him (him). Also including the right to provide property to other entities for use on the basis of ownership, the right of economic management or the right of operational management, or based on other forms of the new regime of property provided by the Civil Code of Ukraine ${ }^{9}$.

The authority of the owner is regulated in Art. 135 of the Civil Code of Ukraine, where it is indicated that the owner of the property has the right to establish commercial organizations individually or jointly with other owners on the basis of property owned by him (or them). Carry out economic activities in other organizational and legal forms of economic are not prohibited by law, determining the purpose at his own discretion and the subject of economic activity, the structure of the enterprise formed by him (or them). The

\footnotetext{
${ }^{7}$ Про цінні папери та фондовий ринок: Закон України від 23 лютого 2006 року № 3480-IV. Відомості Верховної Ради Украӥни. 2006. № 31. Ст. 268.

${ }^{8}$ Вінник О.М. Господарське право. Навчальний посібник. К.: Правова єдність, 2009. C. 206.

${ }^{9}$ Господарський кодекс України 16 січня 2003 року № 436-IV/ Вiдомості Верховної Ради України. 2003. № 18-22. Ст.144.
} 
composition and competence of his (or their) management bodies, the procedure for using property, other issues sys to manage the activities of a economic entity, as well as to decide on the cessation of economic activities of economic entities founded by him (or them) in accordance with the law ${ }^{10}$.

The next property rights in commercial law are the right to conduct business and the right to operational management.

The right to conduct business is the proprietary right of a business entity that owns, uses and disposes of property assigned to it by the owner (the body authorized by it), with the restriction of the authority to order certain types of property with the consent of the owner in cases provided for by the CC and other laws.

The operational management right is understood as the property right of the commercial entity that owns, uses and disposes of the property assigned to it by the owner (body authorized by him) for carrying out non-commercial economic activities, within the limits established by the CC of Ukraine and other laws, as well as property owner (authorized by him authority).

The rights of commercial management and operational management are limited material rights, the subjects of which the powers of ownership, use and disposal of property do not belong in full, but within the limits established by applicable law and the owner ${ }^{11}$. In the case when the real estate being the subject of the dispute is in state ownership and assigned to the plaintiff on the basis of economic management or operational management, according to the contents of art. 136, 137 of the Civil Code Ukraine. Legal competencies of the title holder is protected by law in accordance with the provisions established for the protection of property rights.

The nature of the activities of the subjects of commercial management and operational management also determines the differences in the content of the scope of authority that they receive from the owner of the property assigned to them. The right of economic management, owned by the enterprise as a commercial organization, by virtue of this is wider than the right of operational management, which may belong to nonprofit enterprises, institutions or state-owned enterprises. The object of these rights are property complexes fixed on the balance sheet of the respective legal entities (while remaining the objects of the property rights of their founders $)^{12}$.

10 Господарський кодекс України: навчальний посібник / ред. Н.О. Саніахметова. Харьків: Одісей, 2013. С. 98.

11 Огляд судової практики розгляду Касаційним господарським судом у складі Верховного Суду справ у спорах щодо права власності (за період 3 01.01.2018 по 01.11.2018). URL: https://ips.ligazakon.net/document/ view/VSS00256 (дата звернення: 26.10.2019).

12 Труш І.В. Правовий режим майна комунального підприємства. Економіка та право. 2012. № 2 . 
Commercial Code determines that commercial activity can also be carried out on the basis of other property rights (ownership, use, etc.) provided for by the Civil Code of Ukraine. The property of economic entities can be fixed on another right in accordance with the terms of the contract with the owner of the property.

\section{The concept, signs and types of subjects of commercial legal relations}

The current CC of Ukraine does not contain a definition of the "subject of economic legal relations”. According to art. 2 of the Criminal Code, economic entities, consumers, government bodies and local self-government bodies endowed with economic competence. Public and other organizations acting as founders of economic entities or exercise organizational and economic powers in relation to them, are parties to economic relations: basis of property relations.

However, not all of the listed categories of persons are subjects of economic legal relations (commercial law). Such entities are only those participants in relations in the economic sphere who are inherent in the totality of the necessary attributes for this:

- direct implementation of commercial activity;

- establishment (acquisition of the status of a economic entity) in the order which is prescribed by law;

- the availability of property which is necessary for the implementation of the selected entity or assigned to him economic activities or management of such activities;

- the existence of a commercial legal personality, that is, the ability recognized by the government for a particular subject of commercial relations to be a subject of law.

The concept of the subject of commercial legal relations is defined only in the doctrine of economic law. It is understood as participants in commercial relations who directly carry out commercial activity or manage such activity, created in the order prescribed by law, have the property necessary for carrying out such activity, and have the economic personality ${ }^{13}$.

The entities of commercial legal relations are extremely diverse, however, article 2 of the CC contains their approximate list:

1. Commercial entities.

2. Consumers.

3. Public authorities and local self-government bodies mandated with commercial competence.

\footnotetext{
${ }^{13}$ Вінник О.М. Господарське право. Навчальний посібник. К.: Правова єдність, 2009. C. 62 .
} 
4. Citizens, public and other organizations that act as founders of commercial entities or exercise organizational and economic powers in relation to them on the basis of property rights.

5. At the same time, entities of commercial legal relations, depending on the form of ownership on the basis of which they operate. It be divided into state, communal, collective, private and mixed (operating on the basis of two or more forms of ownership).

\section{Fundamentals of the legal status of commercial entities}

Commercial entities make up the largest and most important group for relations in the field of economic, the main task of which is the organization and implementation of commercial activity in all spheres of social production.

As a general rule, commercial entities include:

1) commercial organizations;

2) entrepreneurs of Ukraine, foreigners and stateless persons who carry out commercial activities and are registered in the order prescribed by law.

Commercial organizations - legal entities established according to Civil Code of Ukraine, state, communal and other enterprises created in accordance with this Code, also other legal entities engaged in commercial activities and registered in the order prescribed by law ${ }^{14}$.

Entrepreneurs are recognized as commercial entities in the case that they carry out economic activities provided that they are registered as an entrepreneur without the status of a legal entity according to art. 58 of the Civil Code of Ukraine. They can carry out entrepreneurial activity on their own, together with other entrepreneurs (on a contractual basis), without creating a legal entity or creating a legal entity (private enterprise or commercial company - traditional, consisting of several people, or society of one person).

The specific of the legal personality of entrepreneurs consists in the scope of their property liability - they are responsible to creditors with all their property, with the exception of property, which, according to the current legislation, is not levied ${ }^{15}$.

Besides, according to the third part of art. 55 of the Criminal Code of Ukraine, commercial entities, depending on the number of employees and income from any activity for the year, can be classified as micro, small, medium and large enterprises ${ }^{16}$.

\footnotetext{
${ }^{14}$ Господарський кодекс України 16 січня 2003 року № 436-IV/ Вiдомості Верховної Ради України. 2003. № 18-22. Ст. 144.

${ }^{15}$ Гусь А.В. Щодо аналізу правового статусу учасників правовідносин із нематеріальними активами. Закон и жизнь. 2013. № 8. С. 125.

${ }^{16}$ Господарський кодекс України 16 січня 2003 року № 436-IV/ Відомості Верховної Ради Украӥни. 2003. № 18-22. Ст. 144.
} 
Essential for the functioning of commercial entities is not only the legitimization of their activities in the manner prescribed by law, but also their implementation of certain types of activities through licensing and patenting.

\section{Features of the legal status of subjects of organizational and commercial powers}

The entities of organizational and economic powers is the entity of economic legal relations (government authority, local government, commercial organization, citizen, foreigner, stateless person), which manages the commercial activities of commercial entities and/or its regulation (of which control is a component) under legal grounds and factual possibilities for this ${ }^{17}$.

For the classification of entities of organizational and commercial powers are the grounds for the occurrence of such powers. The National Economic Legal Doctrine identifies legal (regulatory acts, statutory documents of commercial entities, commercial agreements) and actual (property relations, relations of control and subordination, vesting with organizational and commercial powers to regulate the commercial activities of commercial entities of various forms of ownership, delegation of such powers other entities) grounds for the emergence of organizational and commercial powers.

Thus, the subjects of organizational and commercial powers include:

a) public authorities;

b) local authorities;

c) commercial associations;

d) owners of the property.

Public authorities and local government are not management subjects, they can realize the economic competense (complex form the articles of conduct, functions, powers, rights and duties of public authorities, local government or their public servant or public servant is determined by a constitution ${ }^{18}$ ) through corresponding public or communal institutions.

Economic associations. The distinctive feature of this subject of organizatinal and economic powers is that the creation of economic association with legal entity, an actual subject of the indicated plenary powers is an economic organization from that economically and/or other members of association depend and the legal entity itself is the economic association. In case establishment of economic association without their status of legal entity (holding groups, industrially financial groups (IFG)) separated participant of the group comes forward as the subject of organizational and economic powers : holding company, and in IFG - main enterprise.

\footnotetext{
${ }^{17}$ Кравець I.M. Правове становище суб'єктів організаційно-господарських повноважень: монографія. К.: Юрінком Інтер, 2010. С. 51.

${ }_{18}$ Популярна юридична енциклопедія / В.К. Гіжевський [та ін.] ; голова ред. кол. I. С. Чиж. К.: Юрінком Інтер, 2003. С. 210.
} 
Organizational and economic powers regarding owners of property regarding unitary enterprises and economic societies of one person are determined in the article 135 Commercial Code of Ukraine. Regarding to the property owners of corporative type organizations, then organizational and economic powers appear in case of establishment between an owner and economic organization in regard to that there were corporate laws, relations of decision dependence in understanding in the third part of the article 126 Commercial Code of Ukraine. ${ }^{19}$

\section{General provisions on an economic agreement}

Category "agreement" and "economic agreement" are correlated to a category as a common and special. As the special category of legislation and right in Ukraine an economic agreement has certain legal framework. Term "economic agreement" is widely used in a legislation, legal literature and in economic practice. However a current legislation doesn't contain the decision for economic agreement, although the Commercial code of Ukraine sanctified him a whole head 20 "Economic agreements" (articles 179-188).

The Commercial Code of Ukraine does not render the general decision of economic agreement, however, the analysis of his positions testifies in absence of general approach in relation to understanding of agreement. Thus, in one case an agreement is examined as a legal fact on the basis of that there are economic and contractual obligations (articles 179, 180 Commercial code of Ukraine). In the second case there is his equation with economic obligations (article 189 Commercial Code of Ukraine is named "Price in economic obligations", in spite of the fact that actually the question is about a price as a substantial condition of economic agreement; article 207 Commercial code of Ukraine shows a possibility for a confession about invalidating an economic obligation, it is celled by the participants of economic and contractual relationships with violations even one of their economic competencies, and also separate terms of an economic obligation). In the third - as a form that is acquired by obligations (article 186 Commercial code of Ukraine, which is named "Entering into organizational and economic contracts", envisaged, that contractual registration of organizational and economic obligations can come true by the participants of economic relations on the basis of free will).

An economic legal relationship between two or more subjects, maintenance of which is their contractual obligations to operate in a certain way: to pass and accept property, execute work, render services etc. As the special legal class an economic agreement has the special signs allowing to dissociate him from other types of agreements, including civil:

\footnotetext{
${ }^{19}$ Кравець I.M. Правове становище суб'єктів організаційно-господарських повноважень: монографія. К.: Юрінком Інтер, 2010. С. 137. 128
} 
- special subject structure (usually economic agreements consist with participation of the subjects ( subject) of management; orientation on providing on economic activity from the participants of contractual relations : logistical support of their activity, implementation of the products (works, services) produced by them, joint activity about creating a new subject of management (of economic organization), joint investing, co-ordination in economic activity etc.;

- close connection with planned process, foremost with the a planning of participants in economic relations, and also with national (in relation to subjects, functioning on the national pattern of ownership, enterprises and monopolists) and communal planning (in relation to enterprises and organizations of communal pattern of ownership);

- combination is in economic agreement of property (making or transmission, of the products, its payment etc.) and organizational elements;

- limitations of contractual freedom with the purpose of consumer protection (requirements to quality and safety of commodities, works, services) and general interests;

- possibility of retreat from principle of equality of parties (state contracts, contracts of adhesion, agreements concluded within the framework of scope contracts).

\section{Founding for violation of terms of agreement \\ - grounds and borders of economic and legal responsibility}

As well as any other legal responsibility, economic and legal responsibility is base of certain legal grounds. Firstly, its normative grounds,that is a totality of law rights about responsibility of participants in economic relations. The second founding is economic and legal personality of offender (debtor) and victim (creditor). On application of responsibility in this kind there can parties of legal relationships be management subjects, public authorities and local governments are provided with an economic competencion , and also other participants of economic relations (part 1 article 2; part 1 article 216 Commercial code of Ukraine). The third founding is named legal and actual. She is set in part 1 article 218 Commercial code of Ukraine, in obedience to that founding of economic and legal responsibilities of participant in economic relations is the offence accomplished by him in the field of management ${ }^{20}$. These can be illegal acts or person omission - economic offender that violates rights and legal interests of victim (creditor) or their realization.

This foundation consists of four elements, that in the theory of right which are called the terms of economic and legal responsibility fact of economic offence, losses, causal connection between illegal behavior of violator and

\footnotetext{
${ }^{20}$ Господарський кодекс України 16 січня 2003 року № 436-IV/ Відомості Верховної Ради Украӥни. 2003. № 18-22. Ст.144.
} 
caused to the victim by losses, guilt of offender. Totality (structure) of four adopted terms forms the actual legally economic responsibility.

Article 219 Commercial code of Ukraine set the borders of economic and legal responsibility, and also cases in which responsibility size of participant in economic relations can be decreased or such subject can be released from responsibility ${ }^{21}$.

\section{- methods of providing execution of obligations}

According to part 1 article 199 Commercial code of Ukraine in the relation of providing a fulfilled commitment from participants of economic relations corresponding positions of the Civil code of Ukraine are used. In accordance with an article 546 Commercial code of Ukraine fulfilled commitment can be provided by a forfeit, guarantee, mortgage, withholding, advance. The indicated article, as well as commented, does not contain the exhaustive list of measures to provide a fulfilled commitment, and that is why law or agreement can set other types to provide a fulfilled commitment. For example, in obedience to an article 66 Law of Ukraine "On economic societies"22 participants of general partnership bear solidarity in responsibility about the obligations of society by all of their property. Setting such type of civil liability, a legislator gives to the contractors of the legal entity, created in form of complete society, additional legal methods of providing an execution of obligation. Some forms of non-cash settlements (letter of credit, collection, pre-pay etc.) or even some types of agreements (insurance, credit, leasing, factoring etc.) are provided with securing properties.

Most methods of providing an execution of obligations have accessory character and at ineffectiveness of primary obligation or the termination of its action ceases to exist. But there are such methods of providing that have independent character, for example, guarantee.

Each of the methods to provide an execution of obligations has its certain features conditioned by a degree and influence mechanism on the debtor, but subordinate to one general goal - urge a debtor to carry out an obligation properly.

Only a valid obligation is secured. In this case, the invalidity of the primary obligation(requirements) draws ineffectiveness of transaction on providing the execution. But this commitment does not draw ineffectiveness in the primary obligation.

A transaction on providing the execution of obligation is accomplished in writing form. This requirement is mandatory, therefore, its violation leads to the insignificance of the transaction. Some of methods on providing the execution of obligations requires not simply writing form, but also notarized

\footnotetext{
${ }^{21}$ Господарський кодекс України 16 січня 2003 року № 436-IV/ Вiдомості Верховної Ради Украӥни. 2003. № 18-22. Ст.144.

22 Про господарські товариства: Закон України від 19 версня 1991 року. Відомості Верховної Ради Украӥни. 1991. № 49. Ст. 682.
} 
form of their realization and even special registration, for example, agreement of mortgage.

As for the obligation of state customers under agreements on the basis of government order (state contract), then they are provided by the state represented by Cabinet of Ministers of Ukraine. At the same time, the state guarantees payment for products, work, services under the state contract at the expense of the state budget.

Also, in obedience to paragraph 2 of "Orders of grant of state guarantees on the obligations of Public mortgage institution" ratified by the decision from Cabinet of Ministers of Ukraine from the august 3rd 2006 № 1094. Government guarantees are given on the obligations of public mortgage institution in a size that not exceeds the volume set by Law on the State budget of Ukraine on a corresponding year, when using in full the amount of loans, the repayment of which is guaranteed by the state, in accordance to paragraph 4 of the real "Order". The term of implementation such obligations does not exceed seven years ${ }^{23}$.

\section{CONCLUSIONS}

Taking into account everything mentioned above, commercial law can be defined as a system of legal norms that regulate business relations in the process of organising and running business activities.

The totality of business relations that are established between businesses, their contracting parties and bodies of administration in the process of the organisation and running of business activities, the manufacturing and realisation of goods, the execution of work, and the provision of services constitutes the subject-matter of commercial law.

Commercial law comprises a range of financial-legal and civil-legal norms that in their totality regulate business relations. Financial-legal norms as the rules of conduct that are established by the state are reflected in legal rights and duties of natural persons and business entities. The subjectmatter of financial-legal norms is rules of conduct that arise in the process of business activities of the state and provide for the sound management of material, labour and financial resources; civil-legal norms regulate the relations between business (entrepreneurs).

Commercial law as a science regulates the most important areas of economy irrespective of the form of ownership. In their business activities, state, private, collective, individual, family and joint enterprises must act in accordance with the Commercial Code of Ukraine and laws of market-based economy. Commercial law comprises many economic and legal norms that

23 Питання надання державних гарантій за зобов'язаннями Державної іпотечної установи: постанова Кабінету Міністрів України від 3 серпня 2006 р. № 1094. Офічійний вісник Украӥни. 2006. № 32. Ст. 84. 
regulate entrepreneurship, business, finance and credit relations, assessed taxation, privatization, antitrust and international business activity, etc.

Sources of commercial law may be also legislative and regulatory framework of government bodies and bodies of administration. The norms of commercial law are found in the norms of international law, the Constitution of Ukraine, laws of Ukraine, decrees and regulations of the Cabinet of Ministers of Ukraine, President's decrees, decisions of the state executive bodies and local authorities, orders and instructions of the Ministry of Finance of Ukraine, the National Bank of Ukraine, the State Taxation Administration, etc.

Methods of commercial law are the totality of ways of regulatory control of the norms of commercial law and conduct of subjects of business legal relations.

\section{SUMMARY}

The present article examines some aspects relating to the issue of legal regulation of business relations. Consideration is given to the issue of the legal nature of economic relations in the light of current contradictions between civil and economic codification. The article concentrates on the issue of penetration of public and private origins in the aforementioned sphere. The article aims at providing grounds for identifying commercial law as a special field in the national law system.

\section{REFERENCES}

1. Господарський кодекс України 16 січня 2003 року № 436-IV/ Відомості Верховної Ради України. 2003. № 18-22. Ст. 144.

2. Щербина В.С. До питання щодо принципів господарського права. Вісник Південного регіонального иентру Національної академї правових наук України. 2014. № 1. С. 85-92.

3. Хозяйственное право: учебник / В. К. Мамутов, Г.Л. Знаменский, К. С. Хахулин и др. ; под ред. В. К. Мамутова. Київ: Юринком Интер, 2002. $912 \mathrm{c}$.

4. Цивільний кодекс України від 16 січня 2003 року № 435-IV. Відомості Верховної Ради України. 2003. № 40. Ст. 356.

5. Гусь А.В. Правовий режим нематеріальних активів у складі майна державних вищих навчальних закладів: автореф. дис. ... канд. юрид. наук. спец.: 12.00.04. Київ, 2015. 20 с.

6. Про цінні папери та фондовий ринок: Закон України від 23 лютого 2006 року № 3480-IV. Відомості Верховної Ради Украӥни. 2006. № 31. Ст. 268.

7. Вінник О.М. Господарське право. Навчальний посібник. К.: Правова єдність, 2009. 766 с. 
8. Господарський кодекс України: навчальний посібник / ред. Н.О. Саніахметова. Харьків: Одісей, 2013. 680.

9. Огляд судової практики розгляду Касаційним господарським судом у складі Верховного Суду справ у спорах щодо права власності (за період з 01.01.2018 по 01.11.2018). URL: https://ips.ligazakon.net/ document/view/VSS00256 (дата звернення: 26.09.2019).

10. Труш I.В. Правовий режим майна комунального підприємства. Економіка та право. 2012. № 2.

11. Вінник О.М. Господарське право. Навчальний посібник. К.: Правова єдність, 2009. 766 с.

12. Гусь А.В. Щодо аналізу правового статусу учасників правовідносин із нематеріальними активами. Закон и жизнь. 2013. № 8. C. $121-125$.

13. Кравець І.М. Правове становище суб'єктів організаційно-господарських повноважень: монографія. К.: Юрінком Інтер, 2010. 240 с.

14. Популярна юридична енциклопедія / В.К. Гіжевський [та ін.] ; голова ред. кол. І. С. Чиж. К.: Юрінком Інтер, 2003. 527 с.

15. Про господарські товариства: Закон України від 19 версня 1991 року. Відомості Верховної Ради Украӥни. 1991. № 49. Ст. 682.

16. Питання надання державних гарантій за зобов'язаннями Державної іпотечної установи: постанова Кабінету Міністрів України від 3 серпня 2006 р. № 1094. Офіцฺійний вісник Украӥни. 2006. № 32. Ст. 84.

Information about the author: Lazur Ya. V., Doctor of Law, Professor, Dean of Law Faculty, Uzhhorod National University 26, Kapitulna str., Uzhgorod, 88000, Ukraine 